\title{
PERAN KONSELOR SEKOLAH DALAM PENGEMBANGAN PENDIDIKAN KARAKTER MELALUI PELAYANAN BIMBINGAN KONSELING DI SEKOLAH
}

\author{
Meidy D. Ar Noya S.Th., M.Si ${ }^{1}$, Jenny M. Salamor S.Psi., M.Si ${ }^{2}$ \\ E-mail: eynoya@gmail.com ${ }^{1}$, alamorjenny2489@gmail.com ${ }^{2}$ \\ Program Studi Bimbingan dan Konseling, Universitas Hein Namotemo ${ }^{1,2}$
}

\begin{abstract}
Character education was one of the focuses in the system of national education. Therefore, educators must not neglect this. A school counselor, as one of the educators, has to play a role in character education. Referring to guidance and counseling responsibilities in relation to students' personal, social, academic, and career aspects, a school counselor must not escape from the main duties. Considering that character education is the responsibility of all parties, a school counselor can, independently and in collaboration with all school components, play a role in character education. Individually, a school counselor can provide services, such as individual services, individual planning services, and responsive services. In collaboration with other parties, a school counselor can make a synergy in character education programs. While guidance and counseling services are one of the service programs that contribute to the implementation of the program in schools. So that it is expected that the implementation of strengthening of character education through guidance and counseling services in schools can be implemented and implemented effectively and efficiently, so that it can achieve more optimal goals for the development of character values that exist in students.
\end{abstract}

Keywords: School Counselors; Character Education; Counseling Guidance Services

\begin{abstract}
Abstrak
Pendidikan karakter adalah salah satu fokus dalam sistem pendidikan nasional. Karena itu, pendidik tidak boleh mengabaikan hal ini. Konselor sekolah, sebagai salah satu pendidik, harus berperan dalam pendidikan karakter. Mengacu pada tanggung jawab Bimbingan dan Konseling dalam kaitannya dengan aspek pribadi, sosial, akademik, dan karier siswa, seorang konselor sekolah tidak boleh lepas dari tugas utama. Mempertimbangkan bahwa pendidikan karakter adalah tanggung jawab semua pihak, konselor sekolah dapat, secara independen dan bekerja sama dengan semua komponen sekolah, memainkan peran dalam pendidikan karakter. Secara individual, konselor sekolah dapat memberikan layanan, seperti layanan individu, layanan perencanaan individu, dan layanan responsif. Bekerja sama dengan pihak lain, konselor sekolah dapat membuat sinergi dalam program pendidikan karakter. Pendidikan karakter merupakan salah satu gerakan pendidikan di sekolah untuk memperkuat karakter siswa melalui harmonisasi olah hati (etika), olah rasa (estetika), olah pikiran (literasi), dan olah raga (kinesteti) dengan dukungan melibatkan publik dan kerja sama antar sekolah, keluarga, dan masyarakat. Sementara layanan Bimbingan dan Konseling merupakan salah satu program layanan yang turut andil dalam pelaksanaan program di sekolah. Sehingga diharapkan implementasi penguatan pendidikan karakter melalui pelayanan bimbingan dan konseling di sekolah dapat dilaksanakan dan diterapkan dengan efektif dan efesian, agar dapat mencapai tujuan yang lebih optimal bagi perkembangan nilai-nilai karakter yang ada pada peserta didik.
\end{abstract}

Kata Kunci : Konselor Sekolah; Pendidikan Karakter; Layanan Bimbingan Konseling

PENDAHULUAN

Berbicara tentang Bimbingan dan

Konseling tidak bisa terlepas dari

pendidikan, karena Bimbingan dan

Konseling ada di dalam pendidikan.

Pendidikan bertolak dari hakikat manusia

dan merupakan upaya membantu manusia

dari kondisi obyektif apa adanya (what it is) kepada kondisi bagaimana seharusnya (what should be) (Kartadinata, 2010). Hal ini menggambarkan bahwa pendidikan merupakan aset yang tak ternilai bagi individu dan masyarakat. Namun perlu digarisbawahi bahwa pendidikan tidak bisa diukur atau dideskripsikan hanya dari 
megahnya gedung, fasilitas yang dimiliki atau banyaknya siswa, dan banyaknya personel yang mengelola; karena pendidikan lebih dari itu semua. Pendidikan adalah persoalan fokus dan tujuan. Ia merupakan proses yang esensial dalam mempengaruhi perkembangan manusia (Kartadinata, 2010).

Sebagai suatu proses pendidikan melibatkan berbagai faktor dalam mencapai kehidupan yang bermakna. Karena itu dikatakan mendidik adalah pilihan moral dan bukan pilihan teknis belaka. Menurut Terdapat tiga fungsi pendidikan, yakni (a) fungsi pengembangan, membantu individu mengembangkan diri sesuai dengan segenap potensi dan keunikannya; (b) fungsi peragaman (diferensiasi), membantu individu memilih arah perkembangan yang tepat sesuai dengan potensinya; dan (c) fungsi integratif, membawa keragaman perkembangan ke arah tujuan yang sama sesuai dengan hakikat manusia utnuk menjadi pribadi utuh (kaffah) (Kartadinata, 2010). Fungsi yang terakhir ini bermakna bahwa pendidikan berupaya mengintegrasikan nilai-nilai sosial budaya ke dalam kehidupan peserta didik baik yang menyangkut tatakrama, solidaritas, toleransi, kooperasi maupun empati sehingga peserta didik dapat belajar hidup bermasyarakat secara harmonis.

Untuk mewujudkan pendidikan yang bermutu diharuskan mengintegrasikan tiga bidang kegiatan utamanya yaitu bidang administratif dan kepemimpinan, bidang instruksional dan kurikuler dan bidang pembinaan siswa (Bimbingan dan Konseling yang memandirikan). Pendidikan yang hanya melaksanakan bidang administratif dan pengajaran dengan mengabaikan bidang bimbingan mungkin hanya akan menghasilkan individu yang pintar dan terampil dalam aspek akademik, namun kurang memiliki kemampuan atau kematangan dalam aspek psikososiospiritual (Natawidjaja, 1998, Yusuf dan Nurihsan, 2005). Jadi Bimbingan dan Konseling diperlukan dan merupakan bagian penting dalam upaya pencapaian tujuan pendidikan nasional. Suatu profesi yang bertujuan membantu dan mendukung mengembangkan seluruh potensi dan kompetensi peserta didik sesuai dengan bakat, minat, dan kebutuhannya melalui layanan Bimbingan dan Konseling yang bersifat psikopedagogis. Dalam kaitan ini setumpuk harapan diembankan kepada para penyelenggara layanan Bimbingan dan Konseling di sekolah. Suatu profesi yang diharapkan akan dapat membantu dan mendukung mengembangkan seluruh 
kemampuan peserta didik sesuai dengan potensinya melalui layanan Bimbingan dan Konseling yang bersifat psikopedagogis. Dengan demikian, layanan Bimbingan dan Konseling di sekolah merupakan salah satu bentuk kegiatan pendidikan untuk pencapaian tujuan pendidikan. Harapan besar ditumpukan pada para penyelenggara layanan Bimbingan dan Konseling di sekolah (konselor).

Di dalam pendidikan perjalanan mengemban tugas tersebut, Bimbingan dan Konseling sebagai suatu profesi yang secara legal formal relatif masih muda, banyak mengalami gangguan dan hambatan. Beragam gangguan dan hambatan tersebut, mulai dari jumlah tenaga yang masih terbatas sehingga semua orang "merasa" diperbolehkan melaksanakan tugas tersebut sampai dengan pelaksanaan layanan Bimbingan dan Konseling yang belum optimal.

Akibat berbagai gangguan dann hambatan tersebut menjadi fakta yang terjadi di sekolah selama ini yang menunjukkan bahwa konselor sekolah (guru pembimbing) masih banyak atau sering dipersepsikan secara negatif, seperti guru pembimbing sebagai polisi sekolah, guru pembimbing menakutkan, guru pembimbing hanya menangani anak bermasalah. Kondisi tersebut tentu sangat sulit untuk dapat menuaikan tugas secara umum layanan Bimbingan dan Konseling dengan baik dan komprehensif, terlebih untuk melaksanakan pendidikan karakter. Penyelenggaraan pendidikan karakter banyak memerlukan pendekatan personal, baik dalam arti guru pembimbing harus kompeten dan layak untuk dicontoh, disamping itu juga pada umumnya para siswa akan 'respek' kepada mereka yang memiliki kedekatan secara pribadi sehingga memudahkan terjadinya penyampaian pesan-pesan atau informasi tentang pendidikan karakter. Ada banyak faktor penyebab terjadinya kesalahan persepsi tentang konselor sekolah tersebut di atas, salah satunya kinerja konselor sekolah yang belum maksimal atau belum bisa menunjukkan tugas dan peran yang seharusnya dikerjakan sebagai seorang konselor (Sofyan, 2008).

Penjelasan diatas menunjukkan bahwa betapa pentingnya solusi untuk mengatasi keadaan tersebut. Suatu kondisi yang cukup rumit, mengingat tugas tersebut sudah mendarah daging (habitual performance) bagi para konselor sekolah sebagai pelaksana kesehariannya, namun di pihak lain ternyata kinerja yang tampak belum sesuai dengan harapan. Bukti secara empiris menunjukkan masih banyak siswa yang belum bisa berperilaku secara normative.Hal ini terjadi antara lain 
dari sisi peran yang semestinya dilakukan oleh seorang konselor sekolah dalam pengembangan aspek pribadi dan sosial siswa yang belum maksimal. Walaupun konselor sekolah bukan sebagai satusatunya pihak yang harus atau paling bertanggung jawab terhadap kondisi tersebut, namun konselor sekolah tidak bisa lepas dari tanggung jawab tersebut (Washington, et.all, 2008). Dari perspektif ini, diharapkan tulisan ini dapat memberikan wacana untuk mengurai kerumitan masalah peran yang harus ditampilakn oleh konselor sekolah dalam pengembangan pendidikan karakter melalui pelayanan bimbingan konseling di Sekolah.

\section{METODE PENELITIAN}

Tulisan ini merupakan hasil telaah pustaka untuk mengungkap bentuk peran konselor sekolah dalam pengembangan pendidikan karakter melalui pelayanan bimbingan konseling. Berbagai literatur yang terkait dikaji dengan seksama dan dibandingkan antara yang satu dengan yang lainnya untuk mendapatkan jabaran tentang: (1) Pendidikan Karakter; (2) Posisi Konselor Sekolah dalam Pendidikan Karakter di Indonesia; (3) Konselor Sekolah dalam Kegiatan Pendidikan Karakter; (4) Layanan Bimbingan dan Konseling; (5) dan Implementasi Pendidikan Karakter melalui Pelayanan Bimbingan dan Konseling di Sekolah

\section{HASIL DAN PEMBAHASAN}

\section{Pendidikan Karakter}

Karakter merupakan ciri khusus yang melekat pada seseorang, keluarga, dan komunitas. Pengembangan karakter dimulai dari pembentukan sikap berdasarkan nilai-nilai tertentu, seperti nilai-nilai agama, budaya, termasuk ideologi negara. Karakter seseorang bukanlah hasil dari penilaian terhadap sikap dan perilaku diri sendiri, tetapi merupakan hasil dari penilaian orang lain. Karakter tidak dilahirkan dari retorika mulia atau niat baik semata, tetapi karakter lahir dari kejujuran dan loyalitas yang melekat pada nilai-nilai moral (Josephson. M, 2013).

Pendidikan karakter, konsep pengembangan kesadaran moral pada siswa (LicNona, 1999), muncul dari psikologis, pembelajaran sosial, dan kerangka berpikir perkembangan kognitif. Sebuah tinjauan literatur mengungkapkan keprihatinan dalam menemukan pendekatan yang paling mujarab untuk mengembangkan karakter siswa. Studi dalam pendidikan karakter telah dilakukan di bidang perkembangan kognitif (Gibbs 2006; Narvaez, 2001); kebajikan karakter (LicNona, 1999); dan pembelajaran sosial (Anderson, 2000; Wynne, 1997). 
Pendekatan perkembangan berteori bahwa anak-anak mengembangkan moral secara bertahap. Teori ini dikembangkan oleh Lawrence Kohlberg dan mirip dengan model yang dikembangkan oleh Jean Piaget (Kohlberg, 1989).

Para ahli menafsirkan pendidikan karakter dalam berbagai perspektif, untuk contoh, pendidikan karakter berasal dari tahap pembentukan karakter (Marten, 2004), dimensi psikologis (LicNona, 1991), penilaian moral (Piaget, 1967; Kohlberg; 1976), dan pedagogis pendekatan (Berkowitz, 2002). Marten (2004) menjelaskan bahwa ada tiga tahapan yang harus dilakukan dalam pendidikan karakter, yaitu identifikasi nilai-nilai, nilai pembelajaran dan memberikan kesempatan untuk menerapkan nilai tersebut. Pendidikan karakter psikologis meliputi penalaran moral dimensi, perasaan moral, dan perilaku moral (LicNona, 1991), atau dalam arti moralitas yang mencakup utuh sebagai pertimbangan moral dan perilaku moral baik moralitas yang berdasarkan pada orientasi dan perkembangan moralitas sosial (Piaget, 1967; Kohlberg; 1976).

Pendidikan Karakter yang mengacu pada judul kurikulum yang mendidik siswa tentang seperti peduli, kewarganegaraan, keadilan, rasa hormat, tanggung jawab, dan kepercayaan. Pusat Kurikulum Departemen Pendidikan (Menteri Pendidikan Nasional 2010) menyatakan bahwa untuk lebih memperkuat pelaksanaan pendidikan karakter di satuan pendidikan Indonesia.

Pengembangan Pendidikan Karakter Melalui Pelayanan Bimbingan dan Konseling di Sekolah (Sulma Mafirja \& Jj Sa'Adah) telah mengidentifikasi 18 nilainilai yang berasal dari agama, Pancasila (ideologi nasional), budaya, dan tujuan pendidikan nasional, yaitu :

- Agama: Sikap dan perilaku taat dalam melaksanakan ajaran agama mereka, praktek. agama toleran terhadap orang lain, dan hidup harmonis dengan agama-agama lain.

- Jujur: Perilaku yang berdasarkan pada upaya untuk sesuai dirinya sebagai orang yang selalu dapat dipercaya dalam kata, tindakan, dan pekerjaan.

- Toleransi terhadap Keanekaragaman: Sikap dan tindakan yang menghormati perbedaan agama, ras, etnis, pendapat, sikap, dan tindakan orang lain yang berbeda dari diri mereka sendiri.

- Disiplin: Tindakan yang menunjukkan perilaku tertib dan mematuhi berbagai aturan dan peraturan

- Kerja keras: Tindakan yang 
menunjukkan tertib perilaku dan mematuhi berbagai aturan dan peraturan.

- Kreatif: Melakukan sesuatu untuk menghasilkan cara baru atau hasil dari sesuatu yang telah diselenggarakan

- Independen: Sikap dan perilaku yang tidak mudah tergantung pada orang lain untuk menyelesaikan tugas

- Demokrat: Cara individu dalam berperilaku, dan bertindak hak yang sama dan kewajiban menilai dirinya dan orang lain

- Curiosity: Sikap dan tindakan sebagai mencoba untuk menentukan kedalaman dan penyebaran sesuatu yang dipelajari, dilihat, dan didengar.

- Semangat Kebangsaan: Tindakan, dan suara yang menempatkan kepentingan bangsa dan negara di atas diri sendiri dan kepentingan dan kelompok

- Cinta Tanah Air: Tindakan, dan suara yang menempatkan kepentingan bangsa dan negara di atas diri sendiri dan menghargai kelompok

- Prestasi: Sikap dan tindakan yang mendorong dirinya untuk menghasilkan sesuatu yang berguna bagi masyarakat, mengakui dan menghormati keberhasilan orang lain.

- Ramah / Komunikatif: Sikap dan tindakan yang mendorong dirinya untuk peduli dan lebih aktif terhadap orang lain.

- Cinta Perdamaian: Sikap dan tindakan yang mendorong dirinya untuk cinta akan kedamaian yang ada di lingkungannya.

- Gemar Membaca: Kebiasaan untuk membaca berbagai bacaan yang memberikan kebajikan bagi dirinya

- Peduli Lingkungan: Sikap dan tindakan yang dilakukan untuk mencegah kerusakan alam lingkungan sekitarnya, dan mengembangkan upaya-upaya untuk mencoba dan untuk memperbaiki kerusakan lingkungan yang telah terjadi

- Kepedulian Sosial: Sikap dan tindakan selalu ingin anggota membantu orang lain dan masyarakat yang membutuhkan.

- Tanggung Jawab: Sikap dan perilaku seseorang untuk melak- sanakan tugas dan kewajibannya, yang harus dilakukan, terhadap diri sendiri, masyarakat, lingkungan (alam, sosial, dan budaya), Negara dan Tuhan Yang Maha Esa.

\section{Posisi Konselor Sekolah Dalam} Pendidikan Karakter Di Indonesia Undang-Undang No. 20 Tahun 2003 tentang Sistem Pendidikan Nasional Pasal 3 menggariskan bahwa "Pendidikan 
Nasional berfungsi mengembangkan kemampuan dan membentuk watak serta peradaban bangsa yang bermartabat dalam rangka mencerdaskan kehidupan bangsa, bertujuan untuk berkembangnya potensi peserta didik agar menjadi manusia yang beriman dan bertakwa kepada Tuhan Yang Maha Esa, berakhlak mulia, sehat, berilmu, cakap, kreatif, mandiri, dan menjadi warga negara yang demokratis serta bertanggung jawab”. Dari hal tersebut nampak bahwa pendidikan bukan sekedar berfungsi sebagai media untuk mengembangkan kemampuan semata, melainkan juga berfungsi untuk membentuk watak dan peradaban bangsa yang bermartabat. Dari hal ini maka sebenarnya pendidikan watak (karakter) tidak bisa ditinggalkan dalam berfungsinya pendidikan. Oleh karena itu, sebagai fungsi yang melekat pada keberadaan pendidikan nasional untuk membentuk watak dan peradaban bangsa, pendidikan karakter merupakan manifestasi dari peran tersebut. Untuk itu, pendidikan karakter menjadi tugas dari semua pihak yang terlibat dalam usaha pendidikan (pendidik). Sementara itu, konselor sekolah di dalam UndangUndang Sistem Pendidikan Nasional Tahun 2003 telah diakui sebagai salah satu tenaga pendidik, seperti yang tersurat di dalam Pasal 1, "Pendidik adalah tenaga kependidikan yang berkualifikasi sebagai guru, dosen, konselor, pamong belajar, widyaiswara, tutor, instruktur, fasilitator, dan sebutan lain yang sesuai dengan kekhususannya, serta berpartisipasi dalam menyelenggarakan pendidikan". Dari pengertian tersebut maka konselor sekolah (guru pembimbing merupakan sebutan konselor sekolah sesuai sebutan resmi untuk guru yang mempunyai tugas khusus dalam Bimbingan dan Konseling, menurut Surat Keputusan Bersama Menteri Pendidikan dan Kebudayaan dan Kepala Badan Administrasi Kepegawaian Nasional Nomor 25 Ta- hun 1993) tidak bisa lepas dari fungsi dan tujuan pendidikan tersebut. Dengan kata lain, konselor sekolah mempunyai peran dan tugas yang terkait dengan pendidikan karakter. Sebagai salah satu pihak yang berkepentingan dengan pendidikan karakter ini, konselor sekolah harus berkomitmen untuk melaksanakan pendidikan karakter tersebut (Stone dan Dyal, 1997:22). Beberapa pertimbangan bahwa konselor sekolah harus berperan dalam pendidikan karakter : pertama Konselor Sekolah sebagai konsultan hampir sama dengan tugas sebagai konselor. Sebagai konsultan, konselor sekolah menerima konsultasi dari berbagai pihak lain untuk membantu perkembangan siswa. Pendidikan karakter tidaklah 
mungkin diselesaikan sendiri oleh salah satu pihak. Pendidikan karakter memerlukan keterlibatan semua pihak di sekolah maupun keluarga. Berdasarkan perspektif ini maka semua pihak memiliki peran yang bersifat saling komplementer. Oleh karena itu, konselor sekolah sebagai pihak yang memberikan layanan bersifat psikopedagogis harus mampu memberikan layanan yang bersifat konsultatif atas kepentingan berbagai pihak, mulai dari siswa, guru, orang tua, kepala sekolah, bahkan mungkin sampai dengan masyarakat.

Kedua, konselor sekolah berperan sebagai contoh. Sebagai pendidik konselor sekolah merupakan figur yang menjadi sorotan para siswa khususnya dalam contoh pelaksanaan pendidikan karakter kehidupan sehari- hari di sekolah. Sebagai teladan bagi siswa maka semua aspek kepribadian, penampilan, dan tingkah laku akan menjadi contoh siswa.

Ketiga, konselor sekolah sebagai healer/problem solver, bahwa pelayanan Bimbingan dan Konseling terkait dengan pendidikan karakter terutama melalui bimbingan pribadi dan bimbingan sosial. Dari sudut pandang ini maka peran konselor sekolah nampak ketika membantu memecahkan berbagai permasalahan yang terkait dengan masalah pribadi atau masalah sosial. Hal itu semua sebagai bentuk kegiatan pelayanan responsif dari konselor sekolah. Di samping itu, ketika siswa menghadapi berbagai persoalan yang bersifat pilihan maka peran konselor untuk membantu siswa memilih dapat dilakukan melalui kegiatan perencanaan individual

Keempat, konselor sekolah sebagai konsultan/ mediator. Bahwa pendidikan karakter merupakan tugas dan tanggung jawab semua pendidik di sekolah. Oleh karena itu, konselor akan dapat berperan sebagai patner ataupun sebagai konsultan dalam pelaksanaan pendidikan karakter di sekolah. Bahkan, konsulasi tidak terbatas hanya dengan para pelaksana pendidikan karakter di sekolah (guru, kepala sekolah) tetapi juga dengan para pelaksanan pendidikan karakter di luar sekolah (orang tua, anggota masyarakat). Di samping itu, di mungkinkan juga konselor sekolah bertindak sebagai mediator dalam rangka penyelesaian permasalahan yang dihadapi para siswa.

\section{Konselor Sekolah Dalam Kegiatan Pendidikan Karakter}

Di dalam rambu-rambu penyelenggaraan Bimbingan dan Konseling dalam jalur pendidikan formal termuat dalam lampiran 3 Standar Kompetensi Konselor (Departemen Pendidikan Nasional, 2007:261) 
dijelaskan bahwa pelayanan ahli Bimbingan dan Konseling yang diampu oleh konselor sekolah berada dalam konteks tugas "kawasan pelayanan yang bertujuan memandirikansiswa (individu) dalam memandu perjalanan hidup mereka melalui pengambilan keputusan tentang pendidikan termasuk yang terkait dengan keperluan untuk memilih, meraih serta mempertahankan karir untuk mewujudkan kehidupan yang produktif dan sejahtera, serta untuk menjadi warga masyarakat yang peduli kemaslahatan umum melalui pendidikan". Ekspektasi kinerja konselor yang mengampu pelayanan Bimbingan dan Konseling selalu digerakkan oleh motif altruistik dalam arti selalu menggunakan penyikapan yang empatik, menghormati keragaman, serta mengedepankan kemaslahatan pengguna pelayanannya, dilakukan dengan selalu mencermati kemungkinan dampak jangka panjang dari tindak pelayanannya itu terhadap pengguna pelayanan, sehingga pengampu pelayanan profesional itu juga dinamakan "the reflective practitioner".

Terkait dengan kegiatan pendidikan karakter di sekolah konselor sekolah wajib memfasilitasi pengembangan dan penumbuhan karakter serta tanpa mengabaikan penguasaan hard skills lebih lanjut yang diperlukan dalam perjalanan hidup serta dalam mempersiapkan karier
(Departemen Pendidikan Nasional, 2007:186). Oleh karena itu, konselor sekolah hendaknya merancangkan dalam program kegiatannya untuk secara aktif berpartisipasi dalam pengembangan dan penumbuhan karakter pada siswa. Kegiatan tersebut dapat dilakukan secara mandiri yang terancang dalam program Bimbingan dan Konseling, dan juga bersama-sama dengan pendidik lain (guru bidang studi misalnya) yang terancang dalam program sekolah yang dilakukan secara sinergis dari beberapa pihak. Berkaitan dengan bentuk kegiatan tersebut, maka layanan yang diberikan oleh konselor sekolah dapat bersifat preventif, kuratif, dan preseveratif atau developmental dalam rangka menunaikan fungsi pendidikan dalam mengembangkan karakter siswa. Layanan yang bersifat preventif berarti kegiatan yang dilakukan oleh konselor sekolah bermaksud untuk mencegah agar perilaku siswa tidak berlawanan dengan karakter yang diharapkan. Layanan yang bersifat kuratif bermakna bahwa layanan konselor ditujukan untuk mengobati / memperbaiki perilaku siswa yang sudah terlanjur melanggar karakter yang diharapkan. Kegiatan preseveratif/developmental berarti layanan yang diberikan oleh konselor sekolah bermaksud untuk memelihara dan sekaligus 
mengembangkan perilaku siswa yang sudah sesuai agar tetap terjaga dengan baik, tidak melanggar norma, dan juga mengembangkan agar semakin lebih baik lagi perkembangan karakternya.

\section{Layanan Bimbingan dan Konseling}

Bimbingan dapat diartikan sebagai sesuatu proses pemberian bantuan kepada individu yang dilakukan secara berkesinambungan, supaya individu tersebut dapat memahami dirinya sendiri, sehingga dia sanggup mengarahkan dirinya dan dapat bertindak secara wajar, sesuai dengan tuntutan dan keadaaan lingkungan sekolah, keluarga, masyarakat dan kehidupan pada umumnya, Bimbingan membantu individu mencapai perkembangan diri secara optimal sebagai makhluk sosial. Konseling merupakan suatu upaya bantuan yang dilakukan dengan empat mata atau tatap mukaantara konselor, dan konseli yang berisi usaha yang selaras, unik, human (manusiawi), yang dilakukan dalam suasana keahlian dan yang didasarkan atas norma-norma yang berlaku, agar konseli memperoleh konsep diri dan kepercayaan diri sendiri dalam memperbaiki tingkah lakunya saat ini dan mungkin pada masa yang akan datang.

Secara umum tujuan pelaksanaan layanan Bimbingan dan Konseling adalah berupaya membantu siswa menemukan pribadinya, dalam hal mengenal kekuatan dan kelemahan dirinya, serta menerima dirinya secara positif dan dinamis sebagai modal pengembangan diri lebih lanjut. Jenis layanan Bimbingan dan Konseling terselenggara harus sesuai dengan empat bidang bimbingan yaitu: (1). Bidang bimbingan pribadi (2). Bidang bimbingan sosial (3). Bidang bimbingan belajar (4). Bidang bimbingan karier. (Nur Kholis: 2015).

\section{Implementasi Pendidikan Karakter Melalui Pelayanan Bimbingan Dan Konseling Di Sekolah}

Penerapan pendidikan karakter juga diharapkan tidak akan terlepas dari pelayanan Bimbingan dan Konseling di sekolah. Pelayanan Bimbingan dan Konseling di sekolah merupakan salah satu layanan yang juga dapat memberikan perubahan pada perkembangan dan kemampuan peserta didik, baik dalam proses belajar mengajar, religius, sosial, dan karir dari peserta didik itu sendiri.

Implementasi pendidikan karakter malalui pelayanan Bimbingan dan Konseling di sekolah, diharapkan mampu untuk meningkatkan nilai-nilai karakter yang ada pada peserta didik/siswa. Karena dalam pelayanan Bimbingan dan Konseling itu sendiri sudah menekankan pada empat bidang layanan, yaitu pribadi, sosial, belajar dan karir. Sedangkan dalam 
pendidikan karakter juga lebih menekan kan pada nilai- nilai yang terdiri dari 18 nilai-nilai dan terdiri dari 4 dimensi perkembangan. Pendidikan karakter jauh lebih mungkin untuk bekerja ketika itu dirancang dengan baik, ketika hal itu bergantung pada prinsip- prinsip berbasis penelitian dan kerangka konseptual bermakna, dan ketika itu sepenuhnya dan akurat dilaksanakan.

Guru Bimbingan dan Konseling atau Konselor bertanggung jawab atas kegiatan pembelajaran yang terkait dengan pelayanan Bimbingan dan Konseling untuk sejumlah peserta didik. Oleh sebab itu, disekolah harus diadakan pelayanan Bimbingan dan Konseling. Tujuan pelayanan Bimbingan dan Konseling adalah agar konseli dapat merencanakan kegiatan penyelesaian studi, perkembangan karir serta kehidupannya di masa depan, mengembangkan seluruh potensi dan kekuatan yang dimilikinya seoptimal mungkin, menyesuaikan diri dengan ling- kungan, mengatasi hambatan dan kesulitan yang dihadapi serta pengembangkan karakter secara maksiamal. Adapun manfaat pengembangan karakter melalui layanan Bimbingan dan Konseling ini ialah : (1) agar siswa lebih mandiri dalam menyelesaikan masalahnya, (2) agar siswa lebih bisa menerapkan sopan santun yang baik di kalangan masyarakat, (3) agar siswa bias menghargai setiap proses belajar yang mereka alami baik di sekolah maupun di rumah, dan (4) agar siswa lebih bisa memahami dirinya dengan baik. (Prasetyo, dkk, 2017).

Selain itu, penerapan pendidikan karakter juga tersusun atas tiga bagian, seperti yang dijeskan oleh (Zubaedi, 2011: 13 dalam Ramdhani, 2014) yakni: moral knowing (pengetahuan moral), moral feeling (perasaan moral), dan moral behavior (perilaku moral). Karakter yang baik terdiri dari pengetahuan tentang kebaikan (knowing the good), keinginan terhadap kebaikan (desiring the good), dan berbuat kebaikan (doing the good). Dalam hal ini, diperlukan pembiasaan dalam pemikiran (habits of the mind), dan pembiasaan dalam tindkan (habits of the heart), dan pembiasaan dalam tindakan (habit of the action). Tentunya bagian ini juga sesuai dengan tujuan dari perkembangan dan layanan dalam Bimbingan dan Konseling.

Namun demikian, masih banyak ditemukan dilapangan bahwa Implementasi pendidikan karakter belum menyentuh dimensi penghayatan afektif dan masih jauh dari tataran pengamalan nilai secara nyata dalam tindak perilaku hidup terpelajar sehari-hari. Konsep dasar yang dipergunakan sebagai orientasi 
pendidikan karakter di Indonesia juga tidak jelas ujung pangkalnya. Dari mana berangkatnya dan mau ke mana pendidikan karakter dibawa, landasan filosofisnya tidak mudah ditemukan. Arthur (2014:205) mengamati bahwa gerakan pendidikan karakter ini tidak memiliki perspektif teoretis dan dasar praktek bersama. (dalam Barus, 2015).

Dengan penjelasan di atas maka dapat dipahami bahwa implementasi pendidikan karakter dapat dilakukan dengan mengguanakan layanan dalam Bimbingan dan Konseling yang tentunya tetap menuntut pada perubahan atau perkembangan dari nilai-nilai karakter yang dimiliki oleh peserta didik dan berfokus memang hanya pada perubahan prilaku kearah yang lebih positif dan optimal. Selain itu dalam layanan Bimbingan dan Konseling juga menekankan pada peruabahan tingkah laku atau prilaku dari peserta didiknya dalam menghadapi setiap permasalahan yang mereka hadapi. Walupun dalam implementasinya masih banyak sekolah atau lembaga pendidikan yang belum terlalu paham dan mengerti dari mana awal mulanya akan di kembangakan dan dibentuk pendidikan karakter.

\section{PENUTUP}

Konselor sekolah memiliki tugas yang sangat dekat dan erat dengan misi pendidikan karakter. Kedekatan dan keberatan kewajiban konselor sekolah terhadap pendidikan karakter terlihat secara jelas dari bidang gerak Bimbingan dan Konseling yang berimplikasi bahwa konselor sekolah secara substantif dan fungsional memiliki tugas yang tidak terelakkan. Oleh karena itu, konselor sekolah di Indonesia baik secara langsung maupun tidak langsung berkewajiban menyelenggarakan program pelayanan Bimbingan dan Konseling yang bernuansa nilai-nilai pendidikan karakter. Di samping itu, konselor harus menyiapkan diri untuk melakukan koordinasi dan sinkronisasi sebangai bentuk sinergi pelaksanaan pendidikan karakter. Tidak ketinggalan, sebagai konselor hendaknya mengembangkan nilai-nilai pendidikan karekater melalui kegiatan konseling yang dilakukannya.

\section{DAFTAR PUSTAKA}

Anderson, D. 2000. Character Education: who is responsible? Journal of Instructional Psychology, 27(3), 139

Arthur, J. dalam Larry P. Nucci \&Darcia Narvaez. 2014. Handbook Pendidikan Moral dan Karakter. Bandung: Nusa Media

Gibbs, J. 2006. Should Kohlberg's Cognitive Developmental Approach To Morality Be Replaced With A More Pragmatic Approach? Comments on Krebs and Denton (2005). Psychological Review, 22 (3), 666- 667. 
In A. Molnar. 2005. The Construction of Children's Character The Construction Of Children's Character. Ninety-sixth yearbook of the national society for the study of education (pp. 63-76). Chicago IL: University of Chicago Press.

Josephson, M. 2003. Josephson Institute of Ethics and Character Counts, www.josephsonInstitute.org

(Diakses tgtl 10 Maret 2020)

Kementrian Pendidikan Nasional. 2010. Pembangunan Pendidikan Budaya dan Karakter Bangsa: Pedoman Sekolah. Jakarta: Puskur Balitbang Kemendiknas.

Kohlberg, L. 1976. "Moral Stages and Moralization. The CognitiveDevelopmental Approach." Moral Development and Behavioral: Theory, Research and Issue, Thomas Lickona (ed) News York: Holt, Rinehart, Winston

Lapdley, D.K \& Narvaez, D. 2006. Character education. In $\mathrm{V}$ ol 4 (A. Renninger \& I. Siegal, volume Eds.). Handbook of Child Psychology (Damon \& R. Lerner, Series Eds.) (pp. 248-296). Newww York: Wiley.

Licnona, Thomas. 1999. Characteer Education: The cultibation of Virtue. In C. M. Reigeluth (Ed.), Instructional-design theories and models: A new paradigm of instructional theory (pp. 594-612). Mahwah, NJ: Lawrence Erlbaum Associates

Marten, R. 2004. Successful Coaching, 3th edition, Champaign, IL: Human kinetics
Sidiknas UU No 20 Tahun 2003

Sofyan S. Willis. 2008. "Guru BIMBINGAN DAN KONSELING tak Perlu Beri Solusi". Pikiran Rakyat $17 \quad$ Pebruari 2008. http://www.- pikiranrakyat.com/cetak/2006/042006/07/0702.htm.

Stone, C. and Dyal, M.A. 1997. "School Counselors Sowing the Seeds of Character Education". Professional School Counseling, Dec 1997; 1, 2; pg. 22-24.

Suparno, dkk. 2002. Pendidikan Budi Pekerti di Sekolah. Yogyakarta: Kanisius.

Suparno, dkk. 2002. Pendidikan Budi Pekerti di Sekolah. Yogyakarta: Kanisius.

Washington, E. Y., Clark, M.A. and Dixon, A.L. 2008. "Everyone in School Should Be Involved" Preservice Counselors' Perceptions of Democracy and the Connections Between Character Educat- ion and Democratic Citizenship Education". Journal of Research in Character Education, 6(2), pp. 63-80.

Wynne, E. 1997. For Character Education. In A. Molnar (Ed), The Construction of Children's character The construction of children's character. Ninety-sixth yearbook of the national society for the study of education (pp. 63-76). Chicago, IL: University of Chicago Press.

Zubaedi. 2011. Desain Pendidikan Karakter: Konsepsi dan Aplikasinya dalam Lembaga Pendidikan. Jakarta: Kencana. 